the Director is actually aware of what is going on in the institution which he heads.

Finally, lest it be thought that my previous letter might be construed as "dangerous to the unfettered development of science" 28 , in my estimation it is the current policies of the Public Services Department of the Natural History Museum that are already having just such an effect. I am not opposed to the public presentation of a reasoned case for cladistics, be it transformed or classical, as I have demonstrated by employing cladistic analysis in my own research ${ }^{29}$; nor have $\mathrm{I}$ any objection whatsoever to the presentation of a Marxist interpretation of the history of life, if done in the open and scholarly manner of a Stephen Jay Gould.

My objection is to a major public scientific institution, renowned internationally for its scholarship, to be seen to be abusing its authority by attempting to impose on the general public, against the scientific judgement of its own experts, controversial concepts not by argument or discussion but simply by unsubstantiated assertion.

L. B. HALSTEAD Departments of Geology and Zoology, University of Reading, $U K$

1. Halstead, L. B. Nature 288, $208(1980)$

2. Patterson, C. Nature 288, 430 (1980).

3. Platnick, N. I. Syst. Zool. 26, 438-442 (1977); 28, $537-546$ (1979).

4. Patterson, C. Biologist 27, 234-240 (1980)

5. Hennig, W. Phylogenetic Systematics (Illinois University Press, Urbana, 1966, 1979).

6. Bonde, N. Colloques int. Cent. natn. Rech. scient. 218 , 283-324 (1975).

7. Cracraft, J. Phylogenetic Analysis and Paleontology (eds. Cracraft, J. \& Eldridge, N.) (Columbia University Press, 1979).

8. Hull, D. L. Syst. Zool. 28, 416-440 (1979); Paleobiology6, $131-136(1980)$

9. Fortey, R. Pal. Ass. Circ. 100, 10-11 (1980).

10. Eldridge, N. \& Gould, S. J. in Models in Paleobiology (ed. Schopf, T. J. M.) (Freeman, San Francisco, 1972).

11. Gould, S. J. \& Eldridge, N. Paleobiology 3, 225-151 (1977).

12. Gray, G. K. New Scient. 86, $402(1980)$

13. Hughes-Games, M. J. Nature 288, 430 (1980)

13. Hughes-Games, M. J. Nature 288, $430(1)$
14. Lewin, R. Science $210883-887$ (1980).

Sarwin, C. The Origin of Species by Means of Natural
Selection or the Preservation of Favoured Races in the Struggle for Life (Murray, London, 1859).

16. Mayr, E. Systematics and the Origin of Species (Columbia University Press, 1942); Principles of Systematic Zoology (McGraw-Hill, New York, 1969).

17. Simpson, G. G. Tempo and Mode in Evolution (Columbia University Press, 1944); The Major Features of Evolution (Columbia University Press, 1953); Principles of Animal Taxonomy (Columbia University Press, 1961).

18. Halstead, L. B. in Marx Refuted (eds Duncan, R. \& Wilson, C.) (Pergamon, Oxford, 1981)

19. Stringer, C. Anthropos 7, $81-93$ (1980).

20. Bonde, N. Major Patterns in Vertebrate Evolution (eds Hecht, M. K., Goody, P. C.\& Hecht, B. M.) (Plenum, New York, 1977).

21. Howell, F. C. in Evolution of African Mammals (eds Maglio, V. J. \& Cooke, H. B. S.) (Harvard University Press, 1978).

22. Pilbeam, D. The Evolution of Man (Thames \& Hudson, London, 1970).

23. Washburn, S. L. Scient. Am. 239, 146-154 (1978)

24. Wood, B. The Evolution of Early Man (Peter Lowe, London, 1976)

25. Man's Place in Evolution (British Museum (Natural History) London, 1980).

26. Jelinek, F. in Current Arguments on Early Man (ed. Konigsson, L. -K.) (Pergamon, Oxford, 1980).

27. Wolpoff, M. H. J. hum. Evol. 2, 339-358 (1980).

28. Rothman, H. Nature 288, 430 (1980).

29. Halstead, L. B. in Problems of Phylogenetic Reconstruction (eds Joysey, K. A. \& Friday, A. E.) (Academic, London, 1981).

\section{Science and values}

SiR-Between November 27 and 3019801 attended, as an observer, the 9th International Conference on the Unity of Sciences (ICUS) in Miami Beach. It was host to 640 participants from 85 countries. The concensus of the overwhelming majority of those who attended was that the conference, under the banner "Absolute Values and the Search for the Peace of Mankind"', was a great success. Imagine, then, the consternation with which I read your editorial comment (Nature 27 November p.310) on ICUS "Best not to attend on Mr Moon", which launched scathing broadsides on the founder, seemingly, the aims of the conference, and, indirectly on the integrity of the participants themselves.

Science and values, naturally, reside in different worlds. One cannot understand man's spiritual quest (for liberty, truth, beauty etc.) by empirical laws nor can one restrict scientific endeavour with religious dogma. Yet who can pretend, in a world exhibiting both desperate physical need and social disintegration, that they have nothing to do with each other? This is where I consider the ICUS makes its unique contribution - as an interdisciplinary forum where scholars can freely exchange ideas developed in their own fields about the pressing needs of the world. Few would consider this an "extraneous cause". Are we to understand then, that in referring to Moon's addresses as "vacuous" and implying the term "values" to be meaningless, the editorial policy of Nature is to preserve the steps up the jvory tower of scientific learning unsullied by the muddy boots of morality and social responsibility?

Another point of contention is the assertion that "the participants . . . are (not) the group ideally suited for the discussion of the broad themes . . .". If eminent academics in the fields of science, philosophy and the humanities are not, then who is?

The conclusion of one committee chairman at the end of the Miami conference was that probably more questions had been raised than answered. I would agree with this. The aims of a body like the ICUS are not easily achieved but the challenge to the academic community to work towards the unity of the sciences can only have positive results, more than satisfying merely an intellectual appetite.

\section{London W2, UK}

D.M. TRUBSHAW

\section{NSF and cryptology}

SIR - In view of the extensive recent discussion of the respective roles of the National Science Foundation (NSF) and the National Security Agency (NSA) in support of cryptological research (see, for example,

Nature 4 September, p.2), I believe it may be useful to restate the foundation's established policy in this area.

The essential points of our policy with respect to cryptological research are these:

(1) Since mid-1977 we have routinely referred proposals with relevance to cryptology to NSA for review. We will continue to do this. The practice serves to keep NSA informed of NSF's activities in this area, and gives NSA an opportunity to make technical comments on proposals which can be useful in making funding decisions. It is not a "clearance" process; whatever comments NSA may make are advisory.

(2) NSF has long had a policy of encouraging other agencies to support basic research in areas relevant to their missions. We have specifically encouraged NSA to establish an unclassified basic research programme, and stand ready to assist that agency in this effort. We believe it is fundamentally healthy to have alternative sources of support in important areas of science, and anticipate no difficulties in maintaining close coordination between NSF and NSA.

(3) In cases in which alternative sources of support are available, we routinely encourage principal investigators to apply to such sources as well as to NSF. However, if an investigator prefers to apply only to NSF; we will consider the proposal in the usual manner, without prejudice, and reach a decision on funding using our usual criteria and peer review process.

(4) NSF does not expect that the results of the basic research which it supports will be classified, except in very rare instances. NSF does not currently have classification authority, but it has responsibility, under routine executive orders issued by both the current and previous administrations, to refer any information which it believes might require classification to the agency with appropriate subject matter interest and original classification authority. For cryptological research, that agency is NSA. The important point here is that it makes no essential difference, in terms of the likelihood of classification, whether research is supported by NSF or NSA. This policy is of long standing, and applies to all areas of research.

(5) NSF has long-established reporting requirements which allow it to meet its responsibility for prudent use of public funds. These might not be adequate in all cases where research might have special relevance to national security, and in such cases we may consider special reporting requirements. We have not done this in the past, and we may not have to do it in the future. If we did have to establish such reporting requirements, however, we would regard this not as a change in policy but simply as a change in administrative procedure necessary to apply a long-standing policy to a changed situation.

In summary, the foundation will continue to support cryptological research, will continue to coordinate such research with NSA, and will continue to encourage NSA to develop its own basic research support programme. The results of such research have not been classified in the past, and we do not expect them to be in the future, but we will ensure that our reporting requirements are adequate to allow us to meet our responsibilities with respect to possible classification. Most importantly, the foundation has a basic policy of supporting the best research it can find in all areas of science and engineering, with the fewest possible restrictions on investigators.

DONALD N. LANGENBERG (Acting Director)

National Science Foundation,

Washington, $D C$

\section{Behind the fridge}

SIR-It is highly likely that the reservoir at the back of a self-defrosting refrigerator provides an excellent breeding ground for microorganisms (Nature 20 November 1980, p. 208). However, your correspondent's suggestion that these organisms might cause pulmonary infections such as Legionnaires' disease neglects to consider that they would first have to be dispersed in the form of an aerosol. It is difficult to imagine how this might happen other than when the machine is subject to violent movement.

Public Health Laboratory Service, P.A. Jenkins Mycobacterium Reference Unit, Cardiff, UK 